\title{
Student Teachers' Perceptions toward Elementary Education Student Teaching Program in the Philippines
}

\author{
Virginia O. Rudio*, Rowena D. Carreon, Elma S. Ocampo \\ College of Education, Don Mariano Marcos Memorial State University, Bacnotan, Philippines
}

Received August 26, 2020; Revised October 29, 2020; Accepted November 11, 2020

\section{Cite This Paper in the following Citation Styles}

(a): [1] Virginia O. Rudio, Rowena D. Carreon, Elma S. Ocampo, "Student Teachers' Perceptions toward Elementary Education Student Teaching Program in the Philippines," Universal Journal of Educational Research, Vol. 8, No. 12, pp. 7036 - 7046, 2020. DOI: 10.13189/ujer.2020.081271.

(b): Virginia O. Rudio, Rowena D. Carreon, Elma S. Ocampo (2020). Student Teachers' Perceptions toward Elementary Education Student Teaching Program in the Philippines. Universal Journal of Educational Research, 8(12), 7036 - 7046. DOI: 10.13189/ujer.2020.081271.

Copyright $@ 2020$ by authors, all rights reserved. Authors agree that this article remains permanently open access under the terms of the Creative Commons Attribution License 4.0 International License

\begin{abstract}
The study aimed to assess the student teachers' perceptions toward the Elementary Education Student Teaching Program in Don Mariano Marcos Memorial State University, Philippines. It is a descriptive research that made use of questionnaires as data gathering instruments which were administered to 91 student teachers composed of 10 males and 81 females belonging to age 19 and above. Data were analyzed using frequency counts, percentages and weighted means. All pre-school specialized student teachers from the three batches were exposed to teaching pre-school subjects. Seventy-one (71) general education specialized student teachers also experienced teaching the different subjects in the primary and intermediate levels. The student teaching program is composed of practicum experience variables to be considered by the department which is orientation tasks, rapport with the academic community, practicum environment, auxiliary services and student-teachers activities. Results show that the variables are obtained ratings as 4.49 (HO), 4.99 (VHO), $4.49(\mathrm{HO})$ and 4.56 (VHO) respectively. In a nutshell, the orientation tasks, rapport with the academic community, practicum environment, auxiliary services, and student-teachers activities in the department are highly observed (4.49). The data imply that the department still needs to improve the services along the different parameters to improve further its student teaching program. As such, the experiences of student teachers should really prepare them for the world of work for the future of the next generation rests on the quality of education and training they receive.
\end{abstract}

Keywords Assessment, Perceptions, Student Teaching, Intervention

\section{Introduction}

The quality of education in the Philippines is deteriorating [1]. Factors that could contribute to this problem are the quality of teachers, students, and the academic environment. The teachers in basic education are the foundation of learning (both in the fundamental skills and the knowledge of the subject matter). They are products of the teacher education institutions. Therefore, the student teaching program where they would apply the theories and test the skills learned in their courses must be strong [2]. In the professional growth of teachers, there is an important pioneering stage called student teaching practice. This budding stage in teaching gives students the opportunity to showcase the theoretical knowledge they have learned and apply it in a real classroom setting. According to Goethals and Howard [3], this stage of learning is regarded as the most crucial, the most imposing, but also the most worthwhile stage in teacher education. In addition, Guyton and McIntyre [4] pointed out that student teaching practice is the key element in preparing students in the teaching profession.

The student teaching experience is a complex training that does not only train students what and how to teach. Multiple teaching competencies are trained during student 
teaching. These include: training the right attitude (interpersonal), intercultural competence, training the correct approach in teaching (pedagogy), and other psychological competencies [5]. There are various preparations for student teaching which include micro class teaching, peer tutoring, pedagogy observation of highly competent teachers, and even through lectures. These preparations must be undertaken by student teachers to ensure that their practice teaching will be successful. In his essay entitled 'Teachers in Anglophone Africa: Problems in Teachers' Supply, Education and Management,' Mulkeen [6] found that in Zambia, school teachers were intentionally sent to remote rural schools. Although this may lead to the delivery of teachers, the practical complexities of instruction have increased and, in turn, the frequency of direct monitoring and supervision of student teachers by tutors from the training institution has been decreased. In Malawi, for example, tutors were required to visit each student six times during the teaching practice year (T.P.). Nevertheless, this has been hindered by logistical problems and lack of access to services. The research also determined the effect of T.P. The small role it played in the final evaluation of student teachers has been reduced. For certain cases, the results in T.P. had no effect at all on the student's final score. In Zambia, for example, there has been no analysis of T.P. in the student's average ranking.

In her research, Bhargava [7] observed that the remarks of supervisors remained limited to the use of skills such as chalkboard composition, instruction, class management and media use, and less focus was put on the incremental growth of student teachers, innovative methods and stimuli changes, whether or not they were successfully used in the classroom. The research also showed that training of student teachers did not cover facets of traineeship as a part of the broader society. In a survey called 'Prospective Teachers' Challenges during T.P.' Azeem [8] observed that 20 percent of the participants did not get their lessons reviewed frequently by the supervisors involved, while 80 percent felt that their lessons had been reviewed regularly. However, 23 percent of the participants expressed the view that class teachers were often present in their classrooms during classroom instruction, while the remaining 77 percent expressed the view that class teachers or mentors were frequently not present in their classrooms during prospective instructor teacher preparation.

Hu and Wong [9] in a report called 'College Teachers' Video Conference: Should it? Does it make any difference? 'Examined student teacher trends' chat during T.P... The results showed that cooperating teachers were the ones who had the most conversations with student teachers during T.P ...Student teachers spent the least amount of time interacting with their bosses at their college or university and with school administrators. Although the results of these researchers are relevant to the study's goals, the analyses did not concentrate on prospective teacher expectations and opinions of student teacher supervisors on the efficacy of T.P oversight as a resource for quality control in urban schools in Masvingo.

Enriched understanding of student teacher instruction and assessment interactions when doing practical teaching is projected to make a substantial difference to teacher education awareness at the Don Mariano Marcos Memorial State University (DMMMSU), Philippines by offering valuable information about current practice for student preparation. It is hoped that teacher trainers will be able to use the research as a forum to comment on their experiences and approaches in managing and assessing students teaching in school. The emergence of supervisory-linked problems in teaching practice may be a foundation for solving them through teacher training colleges activities. Researchers have hoped that further research could be inspired by experiences obtained through the research.

\section{Materials and Methods}

\section{Research Design and Sampling Method}

The study used the method of descriptive analysis. A descriptive research approach is a fundamental research method that examines the situation, as it exists in its present state. Descriptive research includes attributes identification of a specific phenomenon in a way that it can be observed as a basis of its interpretation. Furthermore, descriptive research also involves the exploration of correlation between two or more phenomena [10]. In other words, in a descriptive nature, the research focuses on the present situation. Specifically, the descriptive analysis method used in this study is about the compilation and tabulation of data. This involves the description, recording, examination and perception of conditions that exist. Primary source of data were the student interns enrolled under the Bachelor of Elementary Education (BEED) program in the Don Mariano Marcos Memorial State University - North La Union Campus, Philippines for the calendar year 2015-2016. Total enumeration was employed in choosing the respondents. This sampling method was similar to the published descriptive research of Mehdipour et al., [11] where they identified the learning styles of students in Iran. In this present study, all the BEED student teachers were completely enumerated as respondents to identify their perception of the student teaching program in the Philippines.

\section{Data Gathering Instrument}

The instrument used in this study was the practice teaching evaluation form for student interns adopted from Borabo and Lim-Borabo [12]. It is composed of two parts namely, the respondent's profile and part II is the 
practicum experiences. The background of the respondents features the name and address of the partnering teacher, type of school, whether private or public, age, year of graduation, grade / year level taught. The practicum experiences are composed of five sub-parts such as orientation tasks, rapport with the school activity, practicum, site, auxiliary services and student-teachers activities. Recommendations and problems encountered are also provided for the students to write answers freely. After the student teaching program, each intern was requested to fill up the said form as a way of assessing the effectiveness and efficiency of the student teaching program being practiced by the department. Those who did not fill up the evaluation form were accessed via social media and filled up the form also. Interview process also validated the gathered data through the instrument.

\section{Descriptive Equivalence as a Statistical Tool}

According to Perez-Vicente and Ruiz [13], the object of descriptive statistics, from given sample data, is to describe the most relevant characteristics, by which we prefer to those amounts that give information on the theme of interest which we are studying. Hence, the specific problems in this study are categorized as descriptive. The data were analyzed using the number of frequencies, percentages and weighted means. Although no quantitative statistical computation was employed, this present study used descriptive equivalence as a statistical tool. To further elaborate this, a published study by Marin-Blazquez and Shen [14] presented an effective and efficient approach for translating classification rules that uses approximative sets to rules that use descriptive sets and linguistic hedges of predefined meaning. Similar to this present study, a quantitative rating scale and its specified point scale value were used as an approximative set. These approximate sets are translated into descriptive sets with pre-defined linguistic hedges namely, very highly observed (VHO), highly observed (HO), moderately observed (MO), slightly observed (SO), and not observed (NO). For the perception of the student teachers toward the student teaching program along orientation tasks, rapport with the academic community, practicum environment, auxiliary services and student-teachers activities, the following rating scale-range values and descriptive equivalent [15] as follows:

\begin{tabular}{|c|c|c|}
\hline $\begin{array}{c}\text { Rating } \\
\text { Scale }\end{array}$ & $\begin{array}{c}\text { Point Scale } \\
\text { Value }\end{array}$ & Descriptive Equivalence \\
\hline 5 & $4.51-5.0$ & Very Highly Observed (VHO) \\
\hline 4 & $3.51-4.50$ & Highly Observed (HO) \\
\hline 3 & $2.51-3.50$ & Moderately Observed (MO) \\
\hline 2 & $1.51-2.50$ & Slightly Observed (SO) \\
\hline 1 & $1.0-1.50$ & Not Observed (NO) \\
\hline
\end{tabular}

\section{Results and Discussion}

As gleaned from Table 1, $93.10 \%$ (27) of the student interns in 2015 were female, while only $6.90 \%$ (2) are male. In like manner, out of 62 student interns in 2016, $87.10 \%$ (54) and $12.90 \%$ (8) were male. Considering the total respondents for two years, $89.01 \%$ (81) were female and $10.99 \%(10)$ were male. This finding is in consonance with the findings of Burke and Greenglass [16], and Drudy [17], that the teaching profession is dominated by females. In like manner, Simpson [18] and Verdugo and Schneider [19] confirmed this finding that females outnumbered males as indicative of their dominance in the teaching profession. This is attributed to the fact that female teachers possess the characteristics of a mother who is caring, loving, kind, patient and compassionate.

Table 1. Profile of student teachers along sex

\begin{tabular}{|c|c|c|c|c|c|c|}
\hline & 2015 & $\%$ & 2016 & $\%$ & Total & $\%$ \\
\hline \multicolumn{7}{|c|}{ Sex } \\
\hline Male & 2 & 6.90 & 8 & 12.90 & 10 & 10.99 \\
\hline Female & 27 & 93.10 & 54 & 87.10 & 81 & 89.01 \\
\hline $\begin{array}{c}\text { Grand } \\
\text { Total }\end{array}$ & 29 & 100.00 & 62 & 100 & 91 & 100 \\
\hline
\end{tabular}

As to the age of the respondents for both 2015 and 2016, Table 2 presents $38.46 \%$ (35) or more than one-third (1/3) are 20 years old. This is followed by 22 years old and above which is less than one-third and the rest are aged 21 (19.78\%) and 19 years old (10.99\%). This shows that the respondents vary in age though not far in age gaps. These years are considered productive years because the minds of learners are still fast in accepting, processing and retaining information. Moreover, respondents belonging to this age could be full of strength and vigor, hence, can cope with stress brought about by the tasks required in this noble profession. In a broader context, the profile of student teachers along sex and age have been presented because according to Bhargava and Pathy [20], attitude being a social construct is affected by a number of factors such as age, gender, social strata, stream of education and previous job experience. In their study, they regarded the various social constructs to impact the attitude of the teacher, and if, in return they possess a positive attitude, it could help them develop a conducive learner-friendly environment in the classroom. Leyser et al. [21] also agree that age and other variables were associated with the attitudes of educators. Hence, these factors should be considered as major key players that affect teacher preparation programs.

Table 2. The age of the student intern respondents

\begin{tabular}{|c|c|c|c|c|c|c|}
\hline Age & $\mathbf{2 0 1 5}$ & $\mathbf{\%}$ & $\mathbf{2 0 1 6}$ & $\mathbf{\%}$ & Total & $\mathbf{\%}$ \\
\hline 19 & 6 & 20.69 & 4 & 6.45 & 10 & 10.99 \\
\hline 20 & 13 & 44.83 & 22 & 35.48 & 35 & 38.46 \\
\hline 21 & 6 & 20.69 & 12 & 19.35 & 18 & 19.78 \\
\hline $\begin{array}{c}22 \text { and } \\
\text { above }\end{array}$ & 4 & 13.79 & 24 & 38.71 & 28 & 30.77 \\
\hline Total & 29 & 100.00 & 62 & 100 & 91 & 100 \\
\hline
\end{tabular}


As revealed in Table 3, eight out of 29 interns in 2015 were exposed to Pre-school teaching 5 years old learners subjects prescribed under the $\mathrm{K}$ to 12 curriculum. These are English, Filipino, Mathematics and Science. This happens throughout the duration of the in-and off-campus internship because these are the BEED students majoring in Pre-School Education. On the other hand, almost three-fourths (3/4) of the respondents were exposed in teaching Grades I to VI. They are the BEED General Education (Gen Ed) specialists wherein they have to teach all the subjects in any grade level as prescribed in the elementary K-12 curriculum. During their in and off campus practice teaching, the supervisors arranged with the cooperating school the manner to expose these interns. One system is dividing the 9 weeks duration into two wherein during the first shift, half of them are assigned at the primary level and the other half are assigned at the intermediate level.

After 4 weeks, shifting happened to give time for all the interns to experience teaching in the both primary and intermediate levels. Another practice is letting all the student teachers have straight teaching which means that they teach all the subjects in a grade level assigned to them for them to have a feel of how to teach the different subjects in the different grade levels. This holds true during their off-campus teaching again. Exposing them like this will give them experience and this is at their own advantage because when they will apply for a teaching position after graduation, they can draw from their previous experiences, skills and competencies needed to face such diverse learners, hence, won't be experiencing "culture shock" anymore [22]. In the study of Ulla [23], he explored the pre-service teacher training programs in the Philippines through the practicum experience of students from a private university on the island of Mindanao. The student' practice teaching experience is concentrated in developing professionals despite some reported challenges such as classroom management, teaching confidence, and lack of teaching resources.

Table 3. The profile of the respondents as to the grade level and subjects taught

\begin{tabular}{|c|c|c|c|c|}
\hline A. Grade level taught & 2015 & $\%$ & 2016 & $\%$ \\
\hline Pre-School Education (PSE) & 8 & 27.59 & 12 & 19.35 \\
\hline Primary (Grades I-III) & \multirow[b]{2}{*}{21} & \multirow{2}{*}{72.41} & \multirow[b]{2}{*}{50} & \multirow{2}{*}{80.65} \\
\hline Intermediate (Grades IV-VI) & & & & \\
\hline Total & 29 & 100 & 62 & 100 \\
\hline \multicolumn{5}{|l|}{ B. Subjects Taught } \\
\hline Pre-School Education (PSE) Subjects & Primary (I-III) & & Intermediate (IV-VI) & \\
\hline English & English & & English & \\
\hline Filipino & Filipino & & Filipino & \\
\hline Mathematics & Mathematics & & Mathematics & \\
\hline \multirow[t]{5}{*}{ Science } & Science & & Science & \\
\hline & Araling Panlipunan & & Araling Panlipunan & \\
\hline & $\begin{array}{l}\text { Music, Arts, Physical Education } \\
\text { and Health (MAPEH) }\end{array}$ & & $\begin{array}{l}\text { Music, Arts, Physical } \\
\text { Education and Health } \\
\text { (MAPEH) }\end{array}$ & \\
\hline & $\begin{array}{c}\text { Edukasyon sa Pagpapakatao } \\
\text { (ESP) }\end{array}$ & & $\begin{array}{c}\text { Edukasyon sa Pagpapakatao } \\
\text { (ESP) }\end{array}$ & \\
\hline & Mother Tongue & & & \\
\hline
\end{tabular}


Table 4. The result of the respondents' response along orientation tasks

\begin{tabular}{|c|c|c|c|c|c|c|c|c|}
\hline Orientation Tasks & 5 & 4 & 3 & 2 & 1 & & Mean & DE \\
\hline $\begin{array}{l}\text { Orientation of the Student Interns by the } \\
\text { Practicum Supervisor in Practice Teaching }\end{array}$ & 66 & 25 & 0 & 0 & 0 & 430 & 4.73 & VHO \\
\hline $\begin{array}{l}\text { Orientation of the Student Interns by the } \\
\text { Cooperating Principal }\end{array}$ & 53 & 31 & 6 & 1 & 0 & 409 & 4.49 & $\mathrm{HO}$ \\
\hline $\begin{array}{l}\text { Orientation of the Student Interns by the } \\
\text { Cooperating Teacher }\end{array}$ & 56 & 30 & 4 & 1 & 0 & 414 & 4.55 & VHO \\
\hline $\begin{array}{l}\text { Familiarization of the Student Interns on } \\
\text { the School Facilities and Equipment }\end{array}$ & 45 & 40 & 5 & 1 & 0 & 402 & 4.42 & $\mathrm{HO}$ \\
\hline $\begin{array}{c}\text { Orientation on the School Rules and } \\
\text { Policies }\end{array}$ & 52 & 28 & 8 & 2 & 1 & 401 & 4.40 & $\mathrm{HO}$ \\
\hline Orientation on the Required Student Forms & 53 & 29 & 6 & 3 & 0 & 405 & 4.45 & $\mathrm{HO}$ \\
\hline $\begin{array}{c}\text { Practicum Experiences of the Student } \\
\text { Interns }\end{array}$ & 51 & 37 & 3 & 0 & 0 & 412 & 4.53 & $\mathrm{VHO}$ \\
\hline $\begin{array}{c}\text { Consultation Time with the Cooperating } \\
\text { Teacher }\end{array}$ & 53 & 33 & 5 & 0 & 0 & 412 & 4.53 & $\mathrm{VHO}$ \\
\hline Assistance in writing lesson plans & 59 & 24 & 7 & 1 & 0 & 414 & 4.55 & $\mathrm{VHO}$ \\
\hline $\begin{array}{l}\text { Providing feedback on the Student interns } \\
\text { competencies }\end{array}$ & 50 & 33 & 7 & 1 & 0 & 405 & 4.45 & $\mathrm{HO}$ \\
\hline $\begin{array}{l}\text { Meeting with the cooperating teachers on } \\
\text { scheduled basis }\end{array}$ & 49 & 32 & 10 & 0 & 0 & 403 & 4.43 & $\mathrm{HO}$ \\
\hline Giving instructions on classrooms routines & 51 & 34 & 6 & 0 & 0 & 409 & 4.49 & $\mathrm{HO}$ \\
\hline $\begin{array}{l}\text { Providing assistance in making } \\
\text { instructional materials }\end{array}$ & 50 & 31 & 9 & 0 & 1 & 402 & 4.42 & $\mathrm{HO}$ \\
\hline $\begin{array}{c}\text { Giving instructions in checking papers and } \\
\text { other assigned tasks }\end{array}$ & 53 & 29 & 9 & 0 & 0 & 408 & 4.48 & $\mathrm{HO}$ \\
\hline Overall Mean & & & & & & & 4.49 & $\mathrm{HO}$ \\
\hline \multicolumn{9}{|c|}{ Legend: VHO (Very Highly Observed) } \\
\hline
\end{tabular}

In Table 4, respondents' responses ranged from 4.73 (VHO) to 4.40 (HO). Orientation of the Student Interns by the Practicum Supervisor in Practice Teaching topped the list with a rating of 4.73 (Very Highly Observed) followed by Orientation of the Student Interns by the Cooperating Teacher (4.55), Assistance in writing lesson plans (4.55) Practicum Experiences of the Student Interns (4.53) and Consultation Time with the Cooperating Teacher (4.53). The result is attributed to the fact that the Practice teaching supervisor and the cooperating teachers are the people who have direct contact with the student interns. As per practice, before these interns are deployed to the different schools, the ST supervisor spends a weeklong orientation to the student interns. In this period, these interns are given information on the policies, guidelines and standards in practice teaching. Professional ethics of a teacher and other practice teaching related facts are reviewed so these interns are reminded. After the in-school orientation, they are deployed to the different schools in the Department of Education (DepEd). As part of the protocol, they are required to report to the principal before they are turned over to the different cooperating teachers for the actual practice. The cooperating teachers will again conduct orientation on the specific activities or the detailed routine inside the classroom.

Orientation of the Student Teachers by the Practice Teaching Supervisors and cooperating teachers is essential so that student interns can be comfortable and successful during their practice teaching [24], [25], [26]. Proper orientation of students before going on practice teaching exercises will make them confident, to ensure effective teaching and make student teachers feel at ease to teach. The practical experience is a forerunner to student education. Students in the program will study, get to know students and learning preferences, and engage by interacting with particular students or small classes. Practice students will then continue to schedule a few lessons; however, during the practicum, a class takeover is not anticipated. Based on the student's abilities and the teacher's comfort level, some students can behave in a capacity that is above and beyond a few lessons. Ultimately, the realistic experience is to plan student teaching in which complete takeover of the classroom is required [27], [28], [29], [30]. The collaboration between student teachers and cooperating teachers has a very important effect on the growth of student teachers. Many of the students stated that cooperative teachers successfully encouraged certain facets of student teaching. Siwatu [31] stated how Cooperative Teacher Assessment helped student teachers to build effectiveness. Likewise, the value of organized cooperation in student-teacher interaction during education has been widely recognized by many academic papers from several different countries around the world over thirty years studied as reviewed by Ongrsquo and Jwan [32]. Other 
studies on the topic have shown that where teamwork is not well-structured, where there is no common understanding of teaching strategies among participants, and where collaborating teachers are not trained for their roles, there is generally no effective learning for student teachers and that student teachers end up with negative practice exercise [33].

The supervisor should assist the student teacher to become a qualified teacher and also a cooperating teacher should render assistance to the student teachers so that they will see the beauty of their profession. On giving feedback on students' competencies which are rated highly observed, White et al. [34] mentioned that assessment is important to the development of interns and provides an opportunity to identify strengths and weaknesses. The cooperating teacher will be present in the classroom and monitoring teaching while the student teacher continues to interact individually with the pupils. It is necessary for cooperating teachers to give positive feedback about the approach of student teachers to shape partnerships, query skills, concentration and excitement. As the student teacher takes more instructional leadership, there would be more opportunities for the cooperating teachers to provide detailed input on results. It is crucial that this feedback is on-going and honest with recommendations about how student teachers should use approaches and methods to enhance student learning. In connection with the cycle of competence-based supervisory practice, work was also carried out on the student teacher's preference for the feedback mode [35]. Generally, these researches have shown that student teachers tend to be actively involved in the discussions after observation.

The other parameters like Orientation of the Student Interns by the Cooperating Principal (4.49), Familiarization of the Student Interns on the School Facilities and Equipment (4.42), Orientation on the School Rules and Policies(4.40), Orientation on the Required Student Forms (4.45), Providing feedback on the Student interns competencies(4.45), Meeting with the cooperating teachers on scheduled basis( 4.43), Giving instructions on classrooms routines ( 4.49) Providing assistance in making instructional materials ( 4.42), Giving instructions in checking papers and other assigned tasks ( 4.48) are described as highly observed. The average mean of 4.49 under the orientation tasks as a whole is still described as highly observed. This means that these practices need to be improved in order to have a better orientation task for student interns. Specifically, it is implied that the principal of the cooperating school should be willing to assist student teachers. The cooperating school should also make sure that the student teacher is familiar with the facilities and school equipment. The in-house rules and regulations should also be clearly delineated, likewise the routines, meetings, schedules, until the core construction of instructional materials and other assigned tasks should be disseminated and must be thoroughly instilled to the student practice teachers.

Rapport with the students and cooperating teachers underpinned the highest rating of 4.63 and 4.58 respectively (Table 5). This is because interns are directly working with their students and cooperating teachers. Building rapport is a process. Without any interaction with the students, their participation in their lessons would be impaired. Meador [36] said that if you have gained the confidence and admiration of your pupils, anything else would be much simpler. If you're looking forward to your class, you 're looking forward to coming to work every day. In like manner, if there is no rapport with the cooperating teacher, the student intern is left alone. Rapport with the administrators and parents got a rating of 4.40 and 4.33 respectively described as highly observed. For teachers, building rapport with the academic community is important. Community members include students, parents, cooperating teachers and administrators. Building partnerships with students is an aspect that can push teaching to the next level. Teachers realize that this takes time, it's a phase [37], [38. Furthermore, teachers as counselors, can work with parents to enhance the potential to promote successful outcomes for student clients. If counselors are unable to work with parents, they may find their work with the child as undermined or sabotaged by a parent who feels neglected or uninvolved [39].

Table 5. The result along Rapport with the academic community

\begin{tabular}{|c|c|c|c|c|c|c|c|c|}
\hline Rapport with the academic community & $\mathbf{5}$ & $\mathbf{4}$ & $\mathbf{3}$ & $\mathbf{2}$ & $\mathbf{1}$ & & WM & DE \\
\hline Rapport with school administration & 46 & 37 & 7 & 0 & 1 & 400 & 4.40 & HO \\
\hline Rapport with cooperating Teachers & 57 & 30 & 4 & 0 & 0 & 417 & 4.58 & VHO \\
\hline Rapport with students & 61 & 26 & 4 & 0 & 0 & 421 & 4.63 & VHO \\
\hline Rapport with parents & 41 & 39 & 11 & 0 & 0 & 394 & 4.33 & HO \\
\hline Overall Mean & & & & & & 4.49 & HO \\
\hline
\end{tabular}


Cooperating teachers are also part of the academic community. The partnership between the cooperating teacher and the student teacher is a core component of teacher pre-service instruction. When the viewpoint of a partnering teacher contrasts with the viewpoint of a student instructor, the arrangement does not facilitate a seamless transition for a student teacher [40], [41]. Another component of the academic community is the administrators. The best administrators devote an enormous amount of time creating, strengthening and engaging in partnerships. Positive partnerships are at the core of what makes a school remarkable. The Principals could balance the "big picture with the finer detail" and could be multitasking. Bredeson [42] identified these ideals as true leaders who understood when to advise and when to be bold and who displayed the standards, integrity and actions they expected of others.

Table 6 presents the result along the practicum environment. As seen from the table, safety and security of the practicum environment was very highly observed (4.52) by the department in deploying their student teachers. As a teacher education institution, we are responsible for the safety and total development of our student teachers. Whatever will happen to them academically and physically, the college or department is accountable. Student practicum teaching must be well planned. According to Dewey [43], student teaching should be deliberately planned to be as practical and as rigorous as that of actual teaching. It includes the placement of student teachers in schools with deliberately chosen and trained cooperating teachers. The practicum environment is selected on the basis of the type and quality of programs, teachers and school supervisors who provide the best experiences for the student teachers and a challenging workplace for the students. The other variable, accessibility of the practicum environment is rated highly observed (4.45). This means that the department should consider this to facilitate visitation, observation and demonstration of student teachers. According to Ulla [23], understanding the teaching environment to where the practice teachers would be exposed is an essential element towards practicum learning. This experience gives practice teachers the confidence of what they are supposed to do and where they were supposed to do it. Furthermore, knowing the practice teaching environment also provides understanding of the teaching responsibilities, and it also makes educators become competent in their profession.

The quality of auxiliary services rendered to our student interns was rated highly observed (4.41). This means that other extra help offered to our students needs consideration. The college would assist our interns in working out for their other academic needs to facilitate their training. Service quality is indeed necessary in higher education. In the study of Quinn et al. [44], they said that measuring customer satisfaction at an educational establishment might be considered as one of the biggest challenges in terms of service quality. This huge challenge is just one of the many factors that surrounds quality advancement in higher education. In their study, three service areas typically found in higher education were investigated: academic, administrative, and auxiliary functions. Positive research findings on the application of quality techniques for these areas were discovered. This indicates the necessity of having quality auxiliary service in order to assist and essentially mold and develop these visiting practice-teachers.

Table 6. The result along practicum environment

\begin{tabular}{|c|c|c|c|c|c|c|c|c|}
\hline Practicum Environment & $\mathbf{5}$ & $\mathbf{4}$ & $\mathbf{3}$ & $\mathbf{2}$ & $\mathbf{1}$ & & WM & DE \\
\hline Accessibility of the Practicum Environment & 50 & 33 & 7 & 1 & 0 & 405 & 4.45 & HO \\
\hline Safety and Security of the Practicum Environment & 54 & 31 & 5 & 1 & 0 & 411 & 4.52 & VHO \\
\hline Overall Mean & & & & & & & 4.49 & HO \\
\hline Legend: VHO (Very Highly Observed) \\
\hline
\end{tabular}

Table 7. The quality of auxiliary service rendered to students

\begin{tabular}{|c|c|c|c|c|c|c|c|c|}
\hline Auxiliary Services & $\mathbf{5}$ & $\mathbf{4}$ & $\mathbf{3}$ & $\mathbf{2}$ & $\mathbf{1}$ & & WM & DE \\
\hline Quality of Auxiliary Service Rendered & 47 & 36 & 7 & 0 & 1 & 401 & 4.41 & HO \\
\hline
\end{tabular}


Table 8. Student-teachers activities during practicum teaching

\begin{tabular}{|c|c|c|c|c|c|c|c|c|}
\hline Activities of the Student & 5 & 4 & 3 & 2 & 1 & & WM & DE \\
\hline Preparation of daily lessons & 61 & 30 & 0 & 0 & 0 & 425 & 4.67 & VHO \\
\hline Participation in school activities & 59 & 28 & 4 & 0 & 0 & 419 & 4.60 & VHO \\
\hline Preparation of Instructional Materials & 58 & 32 & 1 & 0 & 0 & 421 & 4.63 & VHO \\
\hline Conducting of Demonstration lessons & 63 & 27 & 1 & 0 & 0 & 426 & 4.68 & VHO \\
\hline Assistance in classroom routines & 57 & 29 & 5 & 0 & 0 & 416 & 4.57 & VHO \\
\hline Structuring of bulletin boards & 38 & 41 & 12 & 0 & 0 & 390 & 4.29 & $\mathrm{HO}$ \\
\hline Preparation of seatwork & 52 & 36 & 3 & 0 & 0 & 413 & 4.54 & VHO \\
\hline Preparation of Quizzes & 55 & 32 & 4 & 0 & 0 & 415 & 4.56 & VHO \\
\hline Preparation of other required activities & 50 & 33 & 8 & 0 & 0 & 406 & 4.46 & $\mathrm{HO}$ \\
\hline Mean & & & & & & & 4.56 & $\mathrm{VHO}$ \\
\hline Grand Mean & & & & & & & 4.49 & $\mathrm{HO}$ \\
\hline \multicolumn{9}{|c|}{ Legend: VHO (Very Highly Observed) } \\
\hline
\end{tabular}

As reflected in Table 8, conducting demonstration lessons topped the list of activities with a rating of 4.68 (VHO). Since student teaching is the final term of would-be teachers, it is mostly devoted to practice teaching. It is considered as the most important phase of teacher development. Related to this, the primary objective of student teaching is to provide the opportunity for acquisition and demonstration of instructional competence with beginning professional teachers [45]. Moreover, preparation of daily lesson plans was very highly observed (4.67). As an intern and soon to be full-fledged teacher, lesson planning is very essential. It is the role of the teacher to make daily lesson plans. This will serve as a guide in the implementation of curriculum. Without a plan, the teaching and learning that happens inside the classroom is sacrificed. In relation to this, a detailed lesson plan provides mastery of what to teach, and gives the teacher the confidence when teaching. It also helps a teacher foresee his/her student's reaction and problems in learning. It gives a supervising teacher a chance to see what the student teacher wants to do during practice teaching [46].

In implementing the lesson planned, appropriate instructional materials should be used. Based on the result, preparation of instructional materials was very highly observed (4.63). According to Bilbao et.al., [47] teaching and learning must be supported by instructional materials. Considering the teaching methodologies and learning styles, the different support materials should be varied. This will ensure that the individual differences will be considered. Moreover, instructional materials should complement visual, auditory and tactile or a combination of the three. Participation in school activities got a rating of 4.60 (VHO). Teaching is the noblest profession. Teaching as a job involves the processing of individuals emotional intelligence hoping to transform them into totally developed caring human beings and useful citizens [48]. Likewise, teaching intends to achieve an understanding of its dynamics both inside and outside the classroom suitable for all instructional levels. It also aims to develop the skill in observing and analyzing teacher roles and behavior that provide direction and guidance toward learning efficiency.

Aside from teaching the different subjects, assistance in classroom routines was rated 4.57 (VHO). Classroom management includes managing all the activities not only during instruction but also other classroom routines such as preparation of the learning area and making it conducive for learning. A conducive classroom characterized by well-lighted and a well-ventilated helps teaching-learning process. The physical and emotional environment facilitates acquisition of knowledge; hence, student interns must involve themselves in this as part of their training. Preparation of quizzes and preparation of seatwork was rated 4.56 and 4.54 respectively. In order to ensure that they are learning, a teacher should check for understanding. This is the formative part of the teaching-learning process. This is when you give your daily quizzes or other forms of assessment, the purpose of which is to find out whether your students are "getting it". Constant checking for understanding provides students with a model of good study skills. When their teachers regularly check for understanding, students become increasingly aware of how to monitor their own learning [49]. Competence in preparing assessment tools is a vital skill for any student to acquire. This will help the teacher measure performance of students at the same time check if the objectives are attained.

Preparation of other required activities was rated 4.46 (HO). Planning the lesson "with the end in mind" ensures that the activities that you will provide are designed to close the gap between what students already know and what they need to know [49]. On the other hand, structuring the bulletin boards was rated the least with a rating of $4.29(\mathrm{HO})$. Related to this, bulletin boards are dynamic teaching devices for teachers and students because of the instructional uses [50]. Bulletin board is one of the most readily available and versatile learning 
resources. With these concepts, student teachers must also learn how to prepare bulletin boards as a support to instruction delivery [51]. In totality, student activities are rated 4.56(VHO) which means that the department of elementary education still needs to work on this to ensure a quality student teaching program.

Table 9. Summary of results along practicum experiences

\begin{tabular}{|c|c|c|}
\hline Practicum Experiences & Rating & $\begin{array}{c}\text { Descriptive } \\
\text { Equivalent }\end{array}$ \\
\hline Orientation Tasks & 4.49 & HO \\
\hline $\begin{array}{c}\text { Rapport with the academic } \\
\text { community }\end{array}$ & 4.49 & HO \\
\hline Practicum Environment & 4.49 & HO \\
\hline Auxiliary Services & 4.41 & HO \\
\hline Activities of the Student & 4.56 & VHO \\
\hline Grand Mean & 4.49 & HO \\
\hline Legend: VHO (Very Highly Observed) & HO (Highly Observed) \\
\hline
\end{tabular}

Table 9 presents the summary of results along practicum experiences of the BEED students for CY 2015-2016. The orientation tasks, rapport with the academic community, practicum environment, auxiliary services, and student-teachers activities in the department are highly observed (4.49). The data imply that the department still needs to improve the services along the different parameters to improve further its student teaching program. Student teaching is a school-based experience that is supervised by both experienced and competent cooperating teachers (CT) and a university student teaching supervisor (STS) [52]. As such, the experiences of student teachers should really prepare them for the world of work for the future of the next generation rests on the quality of education and training they receive. From the teacher education institution and the partner school for their practicum experiences. Relative to these observations was the study of Aktas [53] where it was mentioned that there is a need for mentors to be proactive and that there is a genuine supervision of the interaction between the novice teacher and the teacher-supervisor. In essence, a future teacher should be updated professionally, personally and must be rightfully motivated, and at the same time, be committed to the multiple tasks assigned to him/her and execute his/her responsibilities effectively and efficiently [54].

\section{Conclusion}

Student interns for CY 2015-2016 are dominated by females with a ratio of 1:9 and most of them are more than 20 years old. All PSE student interns experienced teaching in the pre-elementary level only while the student interns specialized in general education were exposed teaching in both the primary and intermediate grades, still in the elementary level. As to the perceptions of students along student teaching program offered by the department, orientation tasks is 4.49 (HO), rapport with academic community 4.49 (HO), practicum environment 4.49 (HO), auxiliary services 4.41 (HO), activities of the student 4.56 (HO) with a mean of 4.49 (HO). All are described as highly observed.

\section{Acknowledgements}

We are very grateful to the Don Mariano Marcos Memorial State University for their support in this study.

\section{REFERENCES}

[1] Vizconde C., "English language instruction in the Philippine basic education program,” RELC Journal, vol. 37, no. 2, pp. 260-273, 2006. https://doi.org/10.1177/0033688206067432

[2] Guyton E., Farokhi E., "Relationships among academic performance, basic skills, subject matter knowledge, and teaching skills of teacher education graduates," Journal of Teacher Education, vol. 38, no. 5, pp. 37-42, 1987. https://eric.ed.gov/?id=EJ364361

[3] Goethals M. S., Howard R. A., Stollenwerk D. A., "Student teaching: A process approach to reflective practice: A guide for student, intern, and beginning teachers,” Merrill, 2000.

[4] Guyton E., McIntyre, D.J., "Student teaching and experiences," In W. Robert Houston (Ed.) Handbook of Research on teacher education, pp. 514-534, New York: Macmillan, 1990.

[5] Zindi F., Nyota M., Batidzirayi B., "Improving Teacher Preparation: Teaching Practice Guide,” Harare KAT Printers, Pvt. Ltd., 2003.

[6] Mulkeen A., "Teachers in anglophone africa: issues in teacher supply, training and management. Retrieved 14 June, 2012 from siteresources: worldbank.org, 2010.

[7] Bhargava A., "Teaching practice for student teachers of B. Ed programme issues, predicaments \& suggestions," Turkish Online Journal of Distance Education, vol. 10, no. 2, pp. 101-108, 2009.

[8] Azeem M., "Problems of prospective teachers during teaching practice,” Academic Research International, vol. 1, no. 2, pp. 308, 2011.

[9] Hu C., Wong A. F., "Video conferencing by student teachers: does it make any difference?,” New Horizons in Education, vol. 53, pp. 42-56, 2006. https://eric.ed.gov/?id=EJ847598

[10] Williams C., "Research Methods,” Journal of Business \& Economics Research (JBER), vol. 5, no. 3, 2007. https://doi.org/10.19030/jber.v5i3.2532

[11] Mehdipour M., Mortazavi, H., Yazdani, J., Namdari, M., \& Moradi, M., "Learning styles of dental students at Shahid Beheshti University of Medical Sciences using VARK questionnaire,” Iranian Journal of Medical Education, vol. 18, pp. 176-182, 2018. 
[12] Borabo M.L., Lim-Borabo H.G., "My practice teaching handbook and portfolio," NCBTS-based, Lorimar Publishing, Manila, 2010.

[13] Pérez-Vicente S., Ruiz M. E. "Descriptive statistics.” Allergologia et immunopathologia, vol. 37, no. 6, pp. 314-320, 2009. https://doi.org/10.1016/j.aller.2009.10.005

[14] Marín-Blázquez J. G., \& Shen, Q., "From approximative to descriptive fuzzy classifiers," IEEE Transactions on Fuzzy Systems, vol. 10, no. 4, pp. 484-497, 2002.

[15] Dawes J., "Do data characteristics change according to the number of scale points used? An experiment using 5-point, 7-point and 10-point scales,” International journal of market research, vol. 50, no. 1, pp. 61-104, 2008. https://doi.org/10.1177/147078530805000106

[16] Burke R. J., Greenglass E. R., "Sex differences in psychological burnout in teachers,” Psychological Reports, vol. 65, no.1, pp. 55-63, 1989. https://doi.org/10.2466/pr0.1 989.65.1.55

[17] Drudy S., "Gender balance/gender bias: The teaching profession and the impact of feminisation," Gender and education, vol. 20, no. 4, pp. 309-323, 2008. https://doi.org/10.1080/09540250802190156

[18] Simpson R., "Masculinity at work: The experiences of men in female dominated occupations," Work, employment and society, vol. 18, no. 2, pp. 349-368, 2004. https://doi.org/10.1177/09500172004042773

[19] Verdugo R. R., Schneider J. M., “Gender inequality in female-dominated occupation: The earnings of male and female teachers," Economics of Education Review, vol. 13, no. 3, pp. 251-264, 1994.https://doi.org/10.1016/0272-7757 (94) $90013-2$

[20] Bhargava A., Pathy M., "Attitude of Student Teachers towards Teaching Profession," Turkish Online Journal of Distance Education, vol. 15, no. 3, pp. 27-36, 2014. https://eric.ed.gov/?id=EJ1043694

[21] Leyser Y., Kapperman G., Keller R., “Teacher attitudes toward mainstreaming: a cross nations,” European Journal of Special Needs Education, vol. 9, no. 1, pp. 1-15, 1994 https://doi.org/10.1080/0885625940090101

[22] Hickcox L. K., "Personalizing teaching through experiential learning. College Teaching,” vol. 50, no. 4, pp. 123-128, 2002. https://doi.org/10.1080/87567550209595892

[23] Ulla M. B., "Pre-service teacher training programs in the Philippines: The student-teachers practicum teaching experience,” EFL journal, vol. 1, no. 3, pp. 235-250, 2016.

[24] Borko H., Mayfield V., "The roles of the cooperating teacher and university supervisor in learning to teach,” Teaching and teacher education, vol. 11, no. 5, pp. 501-518, 1995. https://doi.org/10.1016/0742-051X(95)00008-8

[25] Valencia S. W., Martin S. D., Place N. A., Grossman P., "Complex interactions in student teaching: Lost opportunities for learning,” Journal of Teacher Education, vol. 60, no. 3, pp. 304-322, 2009. https://doi.org/10.1177/0022487109336543

[26] Glenn W. J., "Model versus mentor: Defining the necessary qualities of the effective cooperating teacher," Teacher education quarterly, vol. 33, no. 1, pp. 85-95, 2006. https://www.jstor.org/stable/23478736

[27] Koerner M. E., “The cooperating teacher: An ambivalent participant in student teaching," Journal of teacher education, vol. 43, no. 1, pp. 46-56, 1992. https://doi.org/10.1177/0022 48719204300107

[28] Ronfeldt M., Reininger M., "More or better student teaching?," Teaching and teacher education, vol. 28, no. 8, pp. 1091-1106, 2012. https://doi.org/10.1016/j.tate.2012.06. 003

[29] Caruso J. J., "What cooperating teacher case studies reveal about their phases of development as supervisors of student teachers,” European Journal of Teacher Education, vol. 21, no. 1, pp. 109-119, 1998. https://doi.org/10.1080/02619769 80210111

[30] Soslau E., "Opportunities to develop adaptive teaching expertise during supervisory conferences," Teaching and Teacher Education, vol. 28, no. 5, pp. 768-779, 2012. https://doi.org/10.1016/j.tate.2012.02.009

[31] Siwatu K. O., "Preservice teachers' culturally responsive teaching self-efficacy-forming experiences: A mixed methods study," The Journal of Educational Research, vol. 104, no. 5, pp. 360-369, 2011. https://doi.org/10.1080/0022 0671.2010 .487081

[32] Ongrsquo C. O., Jwan J. O., "Research on student teacher learning, collaboration and supervision during the practicum: A literature review,” Educational Research and Reviews, vol. 4, no. 11, pp. 515-524, 2009. https://doi.org/10.5897/ERR.9 000280

[33] Farrell T. S., "Critical incidents in ELT initial teacher training,” ELT journal, vol. 62, no. 1, pp. 3-10, 2008. https://doi.org/10.1093/elt/ccm072

[34] White D. B., Braddock C. H., Bereknyei S., Curtis J. R., "Toward shared decision making at the end of life in intensive care units: opportunities for improvement," Archives of Internal Medicine, vol. 167, no. 5, pp. 461-467, 2007. doi:10.1001/archinte.167.5.461

- cultural study in six

[35] Falender C. A., Shafranske E. P., "Competence in competency-based supervision practice: Construct and application,” Professional psychology: Research and practice, vol. 38, no. 3, pp. 232, 2007. https://doi.org/10.1037/0735-7028.38.3.232

[36] Meador C. A., "Meeting the needs of visually impaired students in washington state: an exploratory study of the working conditions that affect teachers of the visually impaired,” 2015.

[37] Frisby B. N., Martin M. M., "Instructor-student and studentstudent rapport in the classroom," Communication Education, vol. 59, no. 2, pp. 146-164, 2010. https://doi.org/10.1080/03634520903564362

[38] Nguyen, H. T., "Rapport building in language instruction: A microanalysis of the multiple resources in teacher talk," Language and Education, vol. 21, no. 4, pp. 284-303, 2007.

[39] Holcomb-McCoy C., "School counseling to close the achievement gap: A social justice framework for success," Corwin Press, 2007.

[40] Brown A. L., Lee J., \& Collins D., “Does student teaching 
matter? Investigating pre-service teachers' sense of efficacy and preparedness," Teaching Education, vol. 26, no. 1, pp. 77-93, 2015. https://doi.org/10.1080/10476210.2014.95766 6

[41] Hobson L. D., Harris D., Buckner-Manley K., Smith P., "The importance of mentoring novice and pre-service teachers: Findings from a HBCU Student Teaching Program,” Educational Foundations, vol. 26, pp. 67-80, 2012. https://eric.ed.gov/?id=EJ1000231

[42] Bredeson P. V., "The school principal's role in teacher professional development,” Journal of in-service education, vol. 26, no. 2, pp. 385-401, 2000.https://doi.org/10.1080/13 674580000200114

[43] Dewey J., "The relation of theory to practice in education,” Cedar Falls, Iowa: Association for Student Teaching, pp. 9-30, 1962

[44] Quinn A., Lemay G., Larsen P., Johnson D. M., "Service quality in higher education,” Total Quality Management, vol. 20, no. 2, pp. 139-152, 2009. https://doi.org/10.1080/14783 360802622805

[45] Zeichner K., Liston D., “Teaching student teachers to reflect,” Harvard educational review, vol. 57, no. 1, pp. 23-49, 1987. https://doi.org/10.17763/haer.57.1.j18v7162275t1w3w

[46] Kaufmann D., Johnson S. M., Kardos S. M., Liu E., Peske H. G., "Lost At Sea: New Teachers' Experiences with Curriculum and Assessment,” Teachers College Record, vol. 104, no. 2, pp. 273-300, 2002.

[47] Bilbao P., Morano L. N., Barcenal T., Castellano M. A., Nichols S., "Changing traditions of science teacher professional development in the Philippines,” Professional Development in Science Teacher Education: Local Insight with Lessons for the Global Community, vol. 70, 2014.

[48] Mayer J. D., Cobb C. D., "Educational policy on emotional intelligence: Does it make sense?,” Educational psychology review, vol. 12, no. 2, pp. 163-183, 2000. https://doi.org/10.1023/A:1009093231445

[49] Fisher D., Frey N., "Checking for understanding: Formative assessment techniques for your classroom,” ASCD, 2014

[50] Oliver R., "Exploring strategies for online teaching and learning,” Distance education, vol. 20, no. 2, pp. 240-254, 1999. https://doi.org/10.1080/0158791990200205

[51] Schrecker D. L., "Using blogs in academic libraries: versatile information platforms," New library world, vol. 109, no. 3/4, pp. 117-129, 2008. https://doi.org/10.1108/030 74800810857586

[52] Guyton E., "Guidelines for developing educational programs for cooperating teachers," Action in teacher Education, vol. 11, no. 3, pp. 54-58, 1989.

[53] Aktaş, B. C., "Assessment of Induction to Teaching Program: Opinions of Novice Teachers, Mentors, School Administrators," Universal Journal of Educational Research, vol. 6, no. 10, pp. 2101 - 2114, 2018. DOI: 10.13189/ujer.2018.061007.

[54] Lopez N. L., Irene E. A., "Motivation and commitment to teaching among pre-service teachers of a State University in Samar, Philippines,” Journal of Academic Research, vol. 2, no. 3, pp. 18-29, 2017. https://jar.ssu.edu.ph/index.php/JAR /article/view/30 